\title{
Locating Provisioning Ecosystem Services in Urban Forests: Forageable Woody Species in New York City, USA
}

Patrick T. Hurley

Ursinus College, phurley@ursinus.edu

Marla R. Emery

USDA Forest Service

Follow this and additional works at: https://digitalcommons.ursinus.edu/environment_fac

Part of the Environmental Studies Commons, Food Studies Commons, Geographic Information

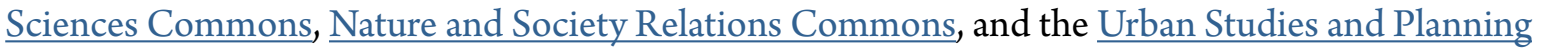
Commons

Click here to let us know how access to this document benefits you.

\section{Recommended Citation}

Hurley, Patrick T. and Emery, Marla R., "Locating Provisioning Ecosystem Services in Urban Forests: Forageable Woody Species in New York City, USA" (2018). Environmental Studies Faculty Publications. 13.

https://digitalcommons.ursinus.edu/environment_fac/13 
Research Paper

\title{
Locating provisioning ecosystem services in urban forests: Forageable woody species in New York City, USA
}

\author{
Patrick Hurley ${ }^{\mathrm{a}, *}$, Marla R. Emery ${ }^{\mathrm{b}}$ \\ a Department of Environmental Studies, Ursinus College, Collegeville, PA, 001. 484.762.4323, USA \\ b Northern Research Station, U.S. Department of Agriculture Forest Service, Burlington, VT, 001.802.656.1721, USA
}

\section{A R T I C L E I N F O}

\section{Keywords:}

Provisioning ecosystem services

Urban green infrastructure

Urban foraging

Non-timber forest products

Urban nature

\begin{abstract}
A B S T R A C T
Scholarship on the ecosystem services provided by urban forests has focused on regulating and supporting services, with a growing body of research examining provisioning and cultural ecosystem services from farms and gardens in metropolitan areas. Using the case of New York, New York, USA, we propose a method to assess the supply of potential provisioning ecosystem services from species and spaces other than those explicitly designated for food production. We analyze the abundance and spatial distribution of trees and shrubs with known uses for food, medicine, craft, and other purposes across urban greenspace types. To do so, we created a database of all woody species known to occur in New York City, joining a citywide assessment of trees and shrubs with additional data from a metropolitan flora and a guide to native plants in the city. A second database of useful, or forageable, species was created by compiling information from a New York City-focused online foraging application and ten field guides chosen for the likelihood that prospective foragers would find and consult them. The City's street tree inventory and associated GIS shapefile provided the basis for more detailed analyses of forageable woody species in this land use type. Our results show a substantial supply of potential provisioning ecosystem services from woody species in New York City. Coupled with growing literature on actual foraging in cities worldwide, these findings suggest implications for accountings of ecosystem services from urban forests as well as policy and management initiatives to enhance social-ecological resilience.
\end{abstract}

"Urban foraging maintains traditions and social ties while deepening connections with nature. Gathering offers positive physical and mental health benefits as well allowing those involved to be part of a larger set of processes related to food and health sovereignty and justice." (Floberg et al., 2013:33)

\section{Introduction}

The City of Seattle's urban forest management handbook lists human foraging amongst the functions and benefits of healthy urban forests, alongside storm water reduction, pollution removal, and terrestrial and aquatic habitat (Floberg et al., 2013). With the statement excerpted above, Seattle is the first city we are aware of to acknowledge provisioning ecosystem services from species and spaces outside those explicitly designated for food production. This policy statement came on the heels of 2 years of dedicated research, which documented over 486 species (433 plants and 53 fungi) foraged there by diverse residents of the largest city in the U.S. State of Washington (Poe, McLain, Emery, \& Hurley, 2013). Other studies have identified urban foraging in countries around the globe, including Germany
(Palliwoda, Kowarik, \& von der Lippe, 2017), India (Unnikrishnan \& Nagendra, 2015), New Zealand (Wehi \& Wehi, 2010), and South Africa (Shackleton, Chinyimba, Hebinck, \& Shackleton, 2015). While these studies probe urban foraging on several continents, to date none has assessed the supply of the plants and fungi on which it relies. Here, we report on results of research to address that gap within the context of ecosystem services from urban green infrastructure.

Over a decade of research documents ecosystem services provided by urban environments. Direct and indirect benefits include regulating services (e.g., amelioration of pollution) and supporting services (e.g., biodiversity; Elmqvist et al., 2013; Haase, Frantzeskaki, \& Elmqvist, 2014). Recent scholarship examines ways urban ecosystems provide food and other materials to city residents (Haase et al., 2014; Barthel, Folke, \& Colding, 2010; Barthel, Parker, \& Ernstson, 2013; Shackleton et al., 2015), as well as social and cultural values (see e.g., Campbell, Svendsen, Sonti, Falxa, \& Johnson, 2016; Cocks, Alexander, Mogano, \& Vetter, 2016). In particular, studies highlight the potential for peri-urban agriculture to supply food to cities (Haase et al., 2014) and urban and community gardens as sites of self-provisioning and

\footnotetext{
* Corresponding author.

E-mail addresses: phurley@ursinus.edu (P. Hurley), memery@fs.fed.us (M.R. Emery).
} 
biocultural knowledge transfer (Barthel et al., 2010, 2013; Barthel, Parker, Folke, \& Colding, 2014). A small but growing body of work demonstrates that urban vegetation outside spaces specifically designated for food production also is a source of provisioning services (Poe et al., 2013; Shackleton et al., 2015; Unikrishnan \& Nagendra 2015), with different greenspace elements providing a diversity of services to city residents (Konijnendijk, 2008; Haase et al., 2014).

Trees are recognized as key to the delivery of many ecosystem services in cities (Nowak, Hoehn, Crane, Stevens, \& Walton, 2007; Chen, Adimo, \& Bao, 2009; Shackleton et al., 2015). However, woody species (defined here as all publicly and privately owned trees and shrubs in an urban area) as sources of provisioning ecosystem services remains understudied (Shackleton et al., 2015). Recent studies have sought to illustrate the ways urban forest species composition may meet food needs (Larondelle \& Strohbach 2016) or assess approaches that can enhance the ability of urban forests to address food security (Clark \& Nicholas 2013), Together with emerging research on urban foraging, these studies demonstrate that the actual and potential ecosystem services provided by urban green infrastructure may be greater than is generally recognized.

Research on foraging in cities throughout the world shows that city residents seek out plant materials and fungi for food, medicine, and utilitarian purposes (Hurley, Emery, McLain, Poe, Grabbatin, \& Goetcheus, 2015; McLain, Hurley, Emery, \& Poe, 2014; Poe et al., 2013; Poe, LeCompteMastenbrook, McLain, \& Hurley, 2014; Shackleton, Shackleton, \& Shanley, 2011; Kaoma \& Shackleton, 2014; Shackleton et al., 2015; Unnikrishnan \& Nagendra 2015). Urban residents forage plant materials and fungi from urban greenspaces that contribute to self-provisioning and support cultural practices. Plants foraged in urban environments are diverse and include intentionally and spontaneously occurring individuals, as well as native and non-native, invasive and non-invasive species. Foraged greenspaces likewise are diverse and include (but are not limited to) cemeteries, institutional campuses, parks, public rights of way, residential yards, and street trees.

To date, however, our understanding of urban foraging derives from a relatively small number of case studies conducted with primarily qualitative methods. While essential to revealing the existence of previously overlooked provisioning ecosystem services from urban forests, this literature is unable to address a number of questions important to considering the ecological implications of urban foraging and its significance for social resilience and human wellbeing. Noteworthy among these is the supply of forageable species.

Using the example of New York City, here we propose a method to assess the inventory of woody species in a city with uses for food, medicine, and utilitarian purposes. In the absence of quantitative data on current foraging practices in the city, we use field guides and a digital database as proxies to identify forageable species. In addition to abundance, our analyses show the spatial distribution of woody species with potential to provide provisioning ecosystem services to the residents of New York City.

In the remainder of this paper, we provide context for the research by briefly summarizing the literature on cities as multi-functional landscapes and emerging scholarship on urban foraging. Following discussion of the study site and methods, we present results of our analyses. These begin with abundance and uses of forageable woody species in all green spaces city wide and in the street tree inventory. We then present findings on the spatial distribution of forageable street trees. Next, we briefly discuss considerations of species desirability for foraging in relation to species abundance citywide and in relation to street trees. We conclude by examining implications for conceptualizing and accounting for provisioning ecosystem services from urban greenspaces.

\subsection{Cities as multifunctional landscapes that provide ecosystem services}

Cities feature multifunctional ecosystems, which provide ecosystem services to urban residents (Konijnendijk, 2008; Haase et al., 2014; McLain et al., 2014; Shackleton et al., 2015). These benefits include flood attenuation (regulating services); pollination (supporting services); food, medicine, and materials (provisioning services); and places important for aesthetics and spirituality (i.e. cultural services; Haase et al., 2014). Urban forests and the woody species in them have key functions in delivering these services (Chen et al., 2009; Chen and Jim, 2008; Chiusura, 2004; Seth, 2003; Tyrväinen, Pauleit, Seeland, \& De Vries, 2005). However, to date urban ecosystem services research has focused primarily on regulating and supporting services provided by them. Given that today more than half the global population resides in cities (Grimm et al., 2008), a more complete understanding of how urban ecosystems, particularly urban forests, enhance human well-being will be critical to addressing urban sustainability challenges (Haase et al., 2014; Hurley et al., 2015). Moreover, cities are sites where research and social-ecological experimentation can address questions about the sustainability of human interactions with urban ecosystem services (Haase et al., 2014). Focusing on the full range of greenspaces, their uses, and functions, is key to better understanding the relationship between the urban forest and the suite of ecosystem services it provides for diverse city residents.

There is growing interest in better understanding provisioning ecosystem services from urban ecosystems (Konijnendijk, 2008; Kaoma \& Shackleton 2014), particularly within the context of a city's green infrastructure. For our purposes, green infrastructure refers to "an interconnected network of green space that conserves natural ecosystem values and functions, and that provides associated benefits to human populations" (Benedict and McMahon, 2012:12). Research on provisioning ecosystem services from urban green infrastructure has focused largely on the capacity of peri-urban agriculture to provide food to cities through conventional supply chains or on urban gardens and self-provisioning by gardeners (Haase et al., 2014). In addition to material benefits, some of these studies also have considered nonmaterial contributions to human well-being (Haase et al., 2014), such as reproduction of culture and knowledge in urban gardens (Barthel et al., 2013, 2014). This work emphasizes agricultural cultivars and human interactions with spaces explicitly set aside for food production, highlighting their contributions to biocultural diversity in cities. Beyond sites designated for agricultural use, diverse urban greenspaces have been shown to provide recreational opportunities and contribute to reduced stress (Konijnendijk, Annerstedt, Nielsen, \& Maruthaveeran, 2013; Maas, Verheij, Groenewegen, de Vries, \& Spreeuwenberg, 2006). These latter studies suggest the ways in which material uses of plants may blur boundaries between ecosystem service categories, with a single practice generating both provisioning and cultural benefits (Reyes-García et al., 2015).

Trees are recognized as providing multiple ecosystem services in cities (Nowak et al., 2007; Chen et al., 2009; Shackleton et al., 2015), in ways that suggest it would be productive to expand studies of provisioning ecosystem service beyond gardens and agricultural cultivars (Barthel et al., 2013, 2014). An emerging body of work has begun to do so, focusing particularly on domesticated fruit trees. Studies conducted in Berlin have identified a historical legacy in the spatial distribution of fruit trees in eastern and western portions of the city (Larondelle and Strohbach, 2016), and demonstrated that consumption of urban-grown fruit poses little risk of exposure to key heavy metals (i.e., lead and cadmium) when handled properly (von Hoffen and Säumel, 2014). Other researchers have identified urban food forestry projects in Canada, the United Kingdom, and United States, while estimating the potential for publically owned greenspaces to contribute to food security if planted with apple trees (Clark and Nicholas, 2013). Questions remain, however, about the full suite of provisioning ecosystem services from urban forests, which of these services are important to which city residents, and how urban greenspaces provide resources to city residents' practices (Konijnendijk, 2008; Haase et al., 2014).

\subsection{Foraging as a mechanism for better understanding the ecosystem services of urban forests}

To address this gap in understanding provisioning ecosystem services 
from urban forests, we turn to insights from research on foraging in cities around the globe. Collectively, these studies provide new insights into the functions of urban forest in delivering material benefits. In New Zealand, some Maori elders forage culturally important medicines in urban environments to avoid harvesting in conservation areas (Wehi and Wehi, 2010). Research conducted in South Africa shows that wild tree fruits and herbaceous species in peri-urban township areas support "history, culture, and heritage" and provide tangible goods including "food, medicines, fodder and fuel wood" (Shackleton et al., 2015:83). Similarly, foraging for plant materials in rapidly urbanizing Bangalore, India provides food and sustains cultural practices for marginalized peoples (D'Souza \& Nagendra, 2011; Unnikrishnan \& Nagendra,2015.

In the United States, foragers harvest items such as nuts, wild berries, and perennial grasses from diverse urban ecosystems, including wooded areas. Foragers interviewed for research conducted in Charleston, New York City, Philadelphia, and Seattle use a wide variety of materials harvested from trees and shrubs for food, medicine, the creation of crafts, and other utilitarian purposes (McLain, Poe, Hurley, Lecompte-Mastenbrook, \& Emery, 2012; Poe et al., 2013, 2014; Hurley et al., 2015). Examples include leaves, blossoms, and sap used to make teas, tinctures, or other medicinal products, and needles, strips of bark, and cones incorporated into baskets. Many of the species from which these plant materials are foraged are wild; that is, they are not cultivars and were not intentionally planted. Others are domesticates, particularly ornamental plantings, for which foraging is an unanticipated and non-sanctioned use (Hurley, Grabbatin, Goetcheus, \& Halfacre, 2012; Poe et al., 2013; Hurley et al., 2015).

The material benefits provided by foraged materials are not confined to self-provisioning. In some instances, they support household economies while contributing to maintenance of cultural identities and fostering ongoing connections with nature. For example, in rapidly (sub)urbanizing coastal South Carolina, USA, African American basketmakers harvest plant materials from four species to support a practice critical to their material and cultural survival, often using basket sales to supplement income from other sources (Hurley et al., 2012, 2015). Research in the United States also demonstrates that urban foraging transcends social identity categories of race, class, age, and gender, even while species and their uses may be culturally differentiated (Robbins, Emery, \& Rice, 2008; McLain et al., 2014; Hurley et al., 2015). Demographic diversity characterizes individuals who have been documented harvesting more than 160 species of plants and four fungi from the urban forests of the Philadelphia Metropolitan area (McLain et al., 2014; Hurley et al., 2015).

These findings suggest provisioning ecosystem services from urban environments are not the exclusive domain of agricultural spaces at the metropolitan periphery or community gardens within the city. Further, the practices and benefits of foraging in urban environments are similar to those found in rural areas (Emery 1998). Ongoing empirical examinations continue to reveal the diversity of urban greenspaces and species that meet urban residents' food, medicine, and raw materials needs (Grabbatin, Hurley, \& Halfacre, 2011; Poe et al., 2013; Hurley et al., 2015), contribute to cultural identity reproduction (Grabbatin et al., 2011; McLain et al., 2014), and bring city residents into meaningful contact with nature (Poe et al., 2014; Hurley et al., 2015). Foraging may involve species in spaces where this practice is not sanctioned and might be deemed inappropriate by managers and landowners (Hurley et al., 2015). The extent and frequency with which specific species and materials are harvested from such spaces remains an open empirical question.

To date foraging research has had little to say about the supply of woody species, in general, and street trees, in particular, for generating provisioning ecosystem services. Greenspaces in which trees and shrubs occur often are widely distributed across urban environments and may be particularly important sources of forageable materials. Thus, there is much to be gained from a focus on woody species and potential provisioning ecosystem services from them. As comparatively long-lived organisms, woody species are enduring elements of urban green infrastructure. The addition (and subtraction) of trees or shrubs to streetscapes and other greenspaces is the focus of municipal programs and budgets, including large tree planting initiatives (Campbell, 2014). They also are the subject of some of the most complete data about vegetation, making them an immediately fruitful arena in which to begin assessing the potential supply of provisioning ecosystem services from urban green infrastructure.

\section{Study site and context}

New York City is home to $19,746,227$ people and covers an area of 122,100 square kilometers (U.S. Census Bureau, 2015). With an urban forest comprised of more than five million trees, 623,000 of which are street trees, New York City ranks second among U.S. cities in the number of trees and ninth in terms of percent of urban tree canopy (Nowak et al., 2007). Fifty-five percent of tree species in the city are native. Like many other cities in the United States and around the world, species diversity in New York is generally higher than in surrounding rural areas, reflecting natural or legacy forests, ruderal dynamics common to abandoned urban spaces, and greenspaces such as parks or institutional campuses and private yards, where ornamental species may dominate (Nowak et al., 2007; Del Tredici, 2010). The value of New York City's trees for carbon sequestration and pollution removal has been estimated at $\$ 41.20$ per acre (Nowak et al., 2007), but their value for other human uses has not been closely examined. Street trees in New York City are part of the city's extensive park system, with management-including species selection-the responsibility of the city's Parks Department. Currently, tharvest of items from the city's parks and street trees is not permissible.

\section{Methods}

Our research considers the potential supply of provisioning ecosystem services from woody species in New York City's urban forest. To do so, we created two databases, which allow us to examine the availability of trees and shrubs with edible, medicinal, and/or other uses: (1) all woody species and (2) forageable species. We then used these data to analyze the spatial distribution and abundance of species present citywide and in the street tree inventory and their uses for food, medicine, and other purposes. Our analysis reveals species that may be useful to residents and the potential benefits they offer. Moreover, our results suggest species that may be particularly abundant and relatively accessible and those that are not particularly abundant but still accessible.

To create the all woody species database, we joined the citywide list of trees and shrubs sampled by Nowak et al. (2007) in their assessment of the New York City urban forest with woody species listed in a guide to native plants in the city (Gargiullo, 2007). The database was further enhanced by adding tree or shrub species listed in the New York Metropolitan Flora Project as occurring in one or more of the city's five boroughs (New York Metropolitan Flora Project, 2015), but not captured in the other sources. The City's publicly available street tree inventory and geographic information system (GIS) shapefile provided a list of woody species over 15 feet in height in this land use category, as well as the base layer for city-wide spatial analyses across land uses and landownerships (New York City Open Data, 2015).

The database of forageable (woody) species in the city draws on an online application and ten field guides (Table 1). These information sources were chosen for the likelihood that prospective foragers would find and consult them based on two criteria: geographic extent that includes New York City and frequency of appearance in repeated searches of a dominant digital bookseller (i.e., Amazon) on the key words "foraging"; "field guides"; and "New York". Given our focus on assessing the extent to which the city's urban forest has the potential to provide these services to residents; we use species as the unit of 
Table 1

Field Guides Sources for Useful Woody Species Database.

\begin{tabular}{|c|c|}
\hline Field Guide Name and Author(s) & Brief Description of contents \\
\hline \multicolumn{2}{|l|}{ Field Guides focused on Edible Uses } \\
\hline $\begin{array}{l}\text { A Field Guide to Edible Wild Plants: Eastern and central North } \\
\text { America }\end{array}$ & $\begin{array}{l}\text { Wild edible plant guide focusing on flowering plants and woody species according to occurrence in non-urban } \\
\text { habitat types. Discussions principally about edible uses. }\end{array}$ \\
\hline \multicolumn{2}{|l|}{ Peterson and Tory Peterson } \\
\hline $\begin{array}{l}\text { Backyard Foraging: } 65 \text { Familiar Plants You Didn't Know You } \\
\quad \text { Could Eat }\end{array}$ & $\begin{array}{l}\text { Approaches foraging from perspective of someone seeking new interactions with species in backyard. Discusses } \\
\text { native, naturalized, and other herbaceous and woody species. }\end{array}$ \\
\hline \multicolumn{2}{|l|}{ Zachos } \\
\hline \multicolumn{2}{|l|}{ Elias and Dykeman } \\
\hline $\begin{array}{l}\text { The Encyclopedia of Edible Plants: Nature's Green Feast } \\
\text { Duke }\end{array}$ & $\begin{array}{l}\text { Volume on useful species found in North America. Includes Native American usages, with consideration of } \\
\text { historical dimensions and ornamental and introduced species. }\end{array}$ \\
\hline $\begin{array}{l}\text { Nature's Garden: A Guide to Identifying, Harvesting, and } \\
\quad \text { Preparing Edible Wild Plants }\end{array}$ & Focuses on 41 widespread edible herbaceous and woody species found in United States. \\
\hline \multicolumn{2}{|l|}{ Thayer } \\
\hline $\begin{array}{l}\text { Northeast Foraging: } 120 \text { Wild and Flavorful Edibles from Beach } \\
\quad \text { Plums to Wineberries }\end{array}$ & Focuses on 120 herbaceous and woody species complexes that contribute to a more diverse cuisine. \\
\hline \multicolumn{2}{|l|}{ Meredith } \\
\hline $\begin{array}{l}\text { Urban Foraging: Finding and Eating Wild Plants in the City } \\
\text { Craft }\end{array}$ & $\begin{array}{l}\text { Not a true field guide, this book introduces foraging in the city. Presents species according to season and ease of } \\
\text { identification. }\end{array}$ \\
\hline Wild Edibles: A Practical Guide to Foraging & Written by son of prominent raw food advocate. Volume focuses on over 60 specific edible plants. \\
\hline \multicolumn{2}{|r|}{${ }^{2}$} \\
\hline \multicolumn{2}{|l|}{ Field Guides focused on both Edible and Medicinal Uses } \\
\hline Wild Edibles Forage App & Smart phone application including more than 250 plants and their edible, medicinal, and other uses. \\
\hline \multicolumn{2}{|l|}{ Brill, Lerner, Nyerges, and WinterRoot } \\
\hline \multicolumn{2}{|l|}{ Field Guides focused on Medicinal Uses } \\
\hline $\begin{array}{l}\text { Field Guide to Medicinal Plants and Herbs of Eastern and Central } \\
\quad \text { North America }\end{array}$ & Focuses on herbaceous and woody species with medicinal uses. \\
\hline \multicolumn{2}{|l|}{ Foster and Duke } \\
\hline $\begin{array}{l}\text { Invasive Plant Medicine: The Ecological Benefits and Healing } \\
\quad \text { Abilities of Invasives }\end{array}$ & Unlike other guides, this volume focuses explicitly on invasive herbaceous and woody. \\
\hline Scott & \\
\hline
\end{tabular}

analysis. However; we recognize that different parts of a single species may have distinct uses For example; mulberry fruits are enjoyed as fresh and prepared foods; while leaves are used to make a tea regarded as having health support benefits. Whether a particular plant material harvested; such as nuts; foliage; bark; or roots; has implications for sustainable supply and management.

Not all forageable species are equally desirable. Where available for woody species in New York City, we employ the quality ratings of the British charity, Plants for a Future (PFAF) as a measure of how appealing a forageable species may be. Plants in the PFAF digital database are chosen for their capacity to be cultivated in temperate climate permaculture settings, with emphasis on "those which have edible, medicinal or other uses" (Plants For a Future, 2015). This database features a fivepoint scale anchored at either end with a score of "1" designating a species with "very minor uses" and " 5 " a species of "great value" for edible, medicinal, and/or other uses. Although subjective in its assessment and based in the United Kingdom, this reference source offers an accessible source of information for researchers and foragers alike and has been used previously in studies of urban food forests to assess the relative merits of species for their potential contributions to food security (Clark and Nicholas, 2013). To assess distribution and abundance of desirable woody species in the city, we conduct spatial analyses combining inventory data and PFAF quality ratings, reporting counts and ratings by zip code.

\section{Results}

\subsection{Forageable woody species, uses, and abundance}

Analysis of the 304 woody species known to be present in New York City shows 252 species with at least one documented edible, medicinal, and/or other use $(83 \%$ of all trees and shrubs found in the city; Table 2). Individual species may have more than one use (that is, edible and medicinal and/or other), derived from one or more plant parts (for example, fruit and leaves and/or twigs). Thus, the numbers of distinct uses of woody species and plant materials used are greater than the total number of forageable species. Our analysis identifies 581 distinct uses (edible, medicinal, or other) with an equal or likely larger number of plant materials providing those functions (i.e. fruits, seeds, blossoms, or leaves, among others). Examining tree species only, 142 have at least one use (88.0\% of all those found in the city), 90 species have all three uses, 33 species have two uses, and 19 have one use. Amongst the 110 shrub species present, 33 have all three uses, 47 have two uses, and 30 have one use.

Medicinal functions make up the largest percentage of all woody species uses (37\%), while edible functions are a close second at 35 percent, and

Table 2

Woody Species Citywide and Street Tree Uses: Count and Percent Based on Known Presence in the City, Inventoried for Abundance, or Present as Street Tree.

\begin{tabular}{|c|c|c|c|c|c|}
\hline & \multicolumn{3}{|l|}{ All Woody } & \multirow[t]{2}{*}{ Citywide } & \multirow{2}{*}{$\begin{array}{l}\text { Street } \\
\text { Trees }\end{array}$} \\
\hline & Total & Trees & Shrubs & & \\
\hline Total Species & 304 & 161 & 143 & 65 & 152 \\
\hline Forageable & 251 & 142 & $109(76 \%)$ & $63(93 \%)$ & 136 \\
\hline Species & $(83 \%)$ & $(88 \%)$ & & & $(89 \%)$ \\
\hline \multicolumn{6}{|c|}{$\begin{array}{l}\text { \# Uses/\# Species (Percent Forageable } \\
\text { species) }\end{array}$} \\
\hline 3 uses & $\begin{array}{l}123 \\
(48 \%)\end{array}$ & $89(63 \%)$ & $34(31 \%)$ & $43(68 \%)$ & $79(58 \%)$ \\
\hline 2 uses & $81(33 \%)$ & $33(23 \%)$ & $48(44 \%)$ & $13(21 \%)$ & $34(25 \%)$ \\
\hline 1 use & $47(19 \%)$ & $20(14 \%)$ & $27(25 \%)$ & $7(11 \%)$ & $23(17 \%)$ \\
\hline Total \# Uses & 577 & 353 & 224 & 162 & 331 \\
\hline \multicolumn{6}{|c|}{ Use Type (Percent Total Uses) } \\
\hline Edible & $\begin{array}{l}201 \\
(35 \%)\end{array}$ & $\begin{array}{l}117 \\
(33 \%)\end{array}$ & $84(37 \%)$ & $62(38 \%)$ & $\begin{array}{l}119 \\
(36 \%)\end{array}$ \\
\hline Medicinal & $\begin{array}{l}214 \\
(37 \%)\end{array}$ & $\begin{array}{l}128 \\
(36 \%)\end{array}$ & $86(38 \%)$ & $50(31 \%)$ & $\begin{array}{l}114 \\
(34 \%)\end{array}$ \\
\hline Other & $\begin{array}{l}162 \\
(28 \%)\end{array}$ & $\begin{array}{l}108 \\
(31 \%)\end{array}$ & $54(25 \%)$ & $50(31 \%)$ & $99(30 \%)$ \\
\hline
\end{tabular}


other functions the smallest percentage (28\%). Considering trees and shrubs separately, trees with at least one medicinal use make up the largest number of total uses $(128$, or $36 \%)$. Trees with at least one edible use comprise the second largest number of total uses (117, or 33\%). Trees with a utilitarian use make up the third largest portion of total uses, with 108 species (31\%) having at least one utilitarian use. Meanwhile, 86 species (38\%) of shrubs have at least one documented medicinal use, $84(37 \%)$ at least one medicinal use, and only 54 species (25\%) another use.

Using just Nowak et al.'s (2007) inventory of the New York City urban forest to assess species presence and abundance of forageable tree species citywide, we find that nearly $93 \%$ of the species identified were one of 63 forageable species (Table 2); London plane and Euonymus trees are the only non-forageable species present. The majority of species $(68 \%)$, at more than a three-to-one ratio, have three functional uses, while 21 percent have two uses and just 11 percent have one use. Of the forageable species present, edible functions predominate, with 62 species $(38 \%)$ featuring edible functions, 50 (31\%) featuring medicinal functions, and $50(31 \%)$ feature other utilitarian uses. When abundance measures are considered, of the estimated 553, 340 trees Nowak et al. (2007) located throughout the city, nearly $94 \%$ of the trees feature some type of use. Delving further into these data, nine of the ten most abundant tree species have edible, medicinal, and/or other uses (Table 3). These include native and nonnative species as well as two species of trees considered invasive (New York Flora Association, 2017). Of the ten most abundant tree species, London plane tree-the only non-forageable species-is present and the most abundant species in the city.

Our analysis of New York City's more than 623,000 street trees ; New York City Open Data (2015) shows similar patterns of potential provisioning ecosystem services in this important component of the public right of way. Some 446,696 street trees (72\%) are forageable. This total includes 136 species. Among these species, 79 species have all three uses, 34 species have two uses, and 23 have one use. In terms of overall abundance, $31 \%$ have three uses, $30 \%$ two uses, and $11 \%$ one use. When individual species abundance is further considered, again nine of the ten most abundant species have edible, medicinal, and other uses (comprising 53\% of all street trees in the city; Table 4). London planetree, the most abundant street tree in the city, once again does not have any foraging uses in our database. As with trees citywide, both native species and nonnative species with edible, medicinal, and other uses are abundant as street trees. Unlike woody species citywide, there are no invasive species found among street tree plantings.

\subsection{Distribution of forageable street trees}

Mapping street trees according to the number of functional uses associated with each tree reveals a rather dramatic picture of the functional utility found within this urban greenspace type (Fig. 1). Species with three or two uses feature prominently throughout the map. Moreover, even in Manhattan, the most densely built portions of the city, the presence of extensive streets with multiple corresponding functional values are visible (upper left). By contrast, the portions of Brooklyn on the lower left illustrate lower densities of trees and fewer individual trees with multiple functional values. Rankwise, the Bronx has the highest average number of uses for its population of trees (1.97 uses), Manhattan is second (1.97), Queens is third (1.95), Staten Island is fourth (1.76), and Brooklyn is last (1.62). Comparison of the percentage of useful street trees present in each borough suggests relatively similar numbers of species, with the Bronx, Manhattan, and Queens each featuring 91 percent of their tree species as useful, while Staten Island and Brooklyn come in with 90 percent and 89 percent of their trees as useful, respectively.

Yet abundances of useful street trees point to differences, with Staten Island and Manhattan having the highest percentage of their trees harboring potential uses (80\%), while just 61 percent of Brooklyn's trees have potential uses. Closer examination of within variation of useful species suggests rather dramatic differences in the relative abundance of particular species within the city (Table 5). For example, while littleleaf linden and pin oak are the two most abundant street tree species in the entire city, total numbers within boroughs vary dramatically. Queens has nearly four times as many linden trees as Manhattan and more than eight times as many pin oak trees. The difference for red maple is nearly 45 times and silver maple more than 100 times as many trees. Given that the latter species might be harvested for their sap, these differences present potentially key barriers to their usage, other questions of practicality and legality notwithsanding.

\subsection{Forageable species desirability, abundance, and distribution}

Analysis of tree species abundance and Plants For a Future's edible and medicinal desirability ratings (2015) reveals additional patterns in abundance and distribution of forageable woody species (Table 4; Fig. 2). In the aggregate, nearly 52 percent of trees city wide have edibility ratings greater than or equal to three (the median possible score). Just over 30 percent of trees have medicinal ratings of at least three. Edible and medicinal ratings are generally less for street trees only (Table 6). Street trees in most zip code areas of the city have combined average ratings for edibles and medicinals of just under 3.0, with those in most of Staten Island much lower for both categories. This pattern is most pronounced for medicinal ratings (Fig. 3). Only a few zip codes, most of them smaller spatial areas located in Manhattan, have combined average ratings of 3.07 or higher (12 of 13 areas, or $92 \%$ ) for edible species and 2.5 or higher (four of five areas, $80 \%$ ) for medicinal species.

When individual species with higher desirability ratings $(>3.00)$ are taken into account, no city-wide or street species appears particularly abundant (Table 6). Among species with higher edibility ratings, only sassafras, littleleaf linden, white mulberry, and ginkgo trees constitute more than two percent of woody species in New York City as a whole. Of these, sassafras is the most abundant city wide and littleleaf

Table 3

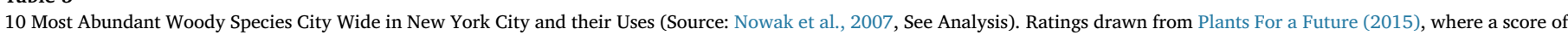

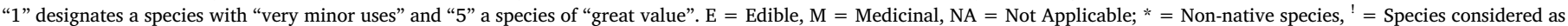
invasive. Note: all species also have other uses. See Plants For a Future (2015) for information about details of uses.

\begin{tabular}{|c|c|c|c|c|}
\hline Common name & Latin name & $\%$ woody species & Uses (Rating) & Examples of Specific Products \\
\hline Tree of Heaven" & Ailanthus altissima & 9.0 & E (1), M (3) & Leaves as famine food, Bark in Traditional Chinese Medicine, Leaves for dye \\
\hline Black Cherry & Prunus serotine & 8.1 & $\mathrm{E}(4), \mathrm{M}(2)$ & Fruits as pies; Bark extract as syrup \\
\hline Sweetgum & Liquidambar styraciflua & 7.9 & $\mathrm{E}(2), \mathrm{M}(3)$ & Resin for chewing gum, antiseptic, soap \\
\hline Northern red oak & Quercus rubra & 7.7 & $\mathrm{E}(3), \mathrm{M}(2)$ & Acorn as coffee, bark as antiseptic, bark for dye \\
\hline Norway maple ${ }^{*}$ & Acer platanoides & 6.0 & $\mathrm{E}(2)$ & Sap as sweetener, bark as dye \\
\hline White mulberry" & Morus alba & 5.7 & E (4), M (3) & Fruit, dried raisin substitute, Leaves famine food, Multiple parts in Traditional Chinese Medicine \\
\hline Sassafras & Sassafras albidum & 4.8 & E (5), M (3) & Raw leaves for salad, cooked leaves for soups; Root bark as antiseptic \\
\hline Black locust ${ }^{* !}$ & Robinia pseudoacacia & 4.7 & $\mathrm{E}(3), \mathrm{M}(2)$ & Seed cooked; Flowers cooked for jams; Bark for dye; Flowers for essential oil \\
\hline London planetree & Platanus $x$. acerifolia & 3.6 & NA & None \\
\hline Red maple & Acer rubrum & 3.6 & $\mathrm{E}(3), \mathrm{M}(1)$ & Sap as syrup, Inner bark for dye \\
\hline
\end{tabular}


Table 4

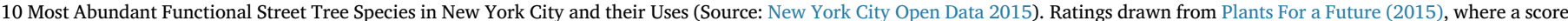

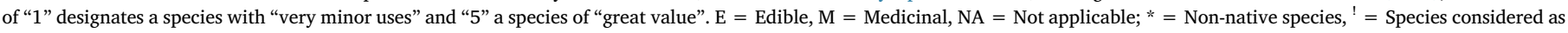
invasive. Note: all species also have other uses. See Plants For a Future (2015) for information about details of uses.

\begin{tabular}{|c|c|c|c|c|}
\hline Common name & Latin name & $\%$ street tree species & Uses (Rating) & Examples of Specific Products \\
\hline Lond & Platanus $x$. acerifolia & 12.0 & NA & None \\
\hline Norway maple" & Acer platanoides & 12.0 & $\mathrm{E}(2)$ & Sap as sweetener, bark as dye \\
\hline Callery pear* & Pyrus calleryana & 10.2 & $\mathrm{E}(2)$ & Fruit raw or cooked for jams \\
\hline Honey locust & Gleditsia triacanthos & 8.4 & $\mathrm{E}(3), \mathrm{M}(2)$ & Seed as coffee, seedpod as sweetener \\
\hline Pin oak & Quercus palustris & 7.0 & $\mathrm{E}(3), \mathrm{M}(2)$ & Acorn as thickener, leaves for insect repellent \\
\hline Littleleaf linden & Tilia cordata & 4.4 & E (5), M (3) & Leaves as greens, flowers for tea, inner bark for fiber \\
\hline Green ash & Fraxinus pennsylvanica & 3.3 & $\mathrm{E}(1), \mathrm{M}(1)$ & Leaves as bitter tonic, bark for dye and basketry \\
\hline Red maple & Acer rubrum & 3.3 & $\mathrm{E}(3), \mathrm{M}(1)$ & Sap as syrup, Inner bark for dye \\
\hline Silver maple & Acer saccarhinus & 3.0 & $\mathrm{E}(3), \mathrm{M}(1)$ & Sap for sweetener, seed cooked, stems for baskets, twigs for dye \\
\hline Ginkgo & Ginkgo biloba & 2.6 & $\mathrm{E}(5), \mathrm{M}(5)$ & Seed eaten raw or cooked, Fruit, seed, and leaves in Traditional Chinese Medicine \\
\hline Northern red oak & Quercus rubra & 1.8 & $\mathrm{E}(3), \mathrm{M}(2)$ & Acorn as coffee, bark as antiseptic, bark for dye \\
\hline
\end{tabular}
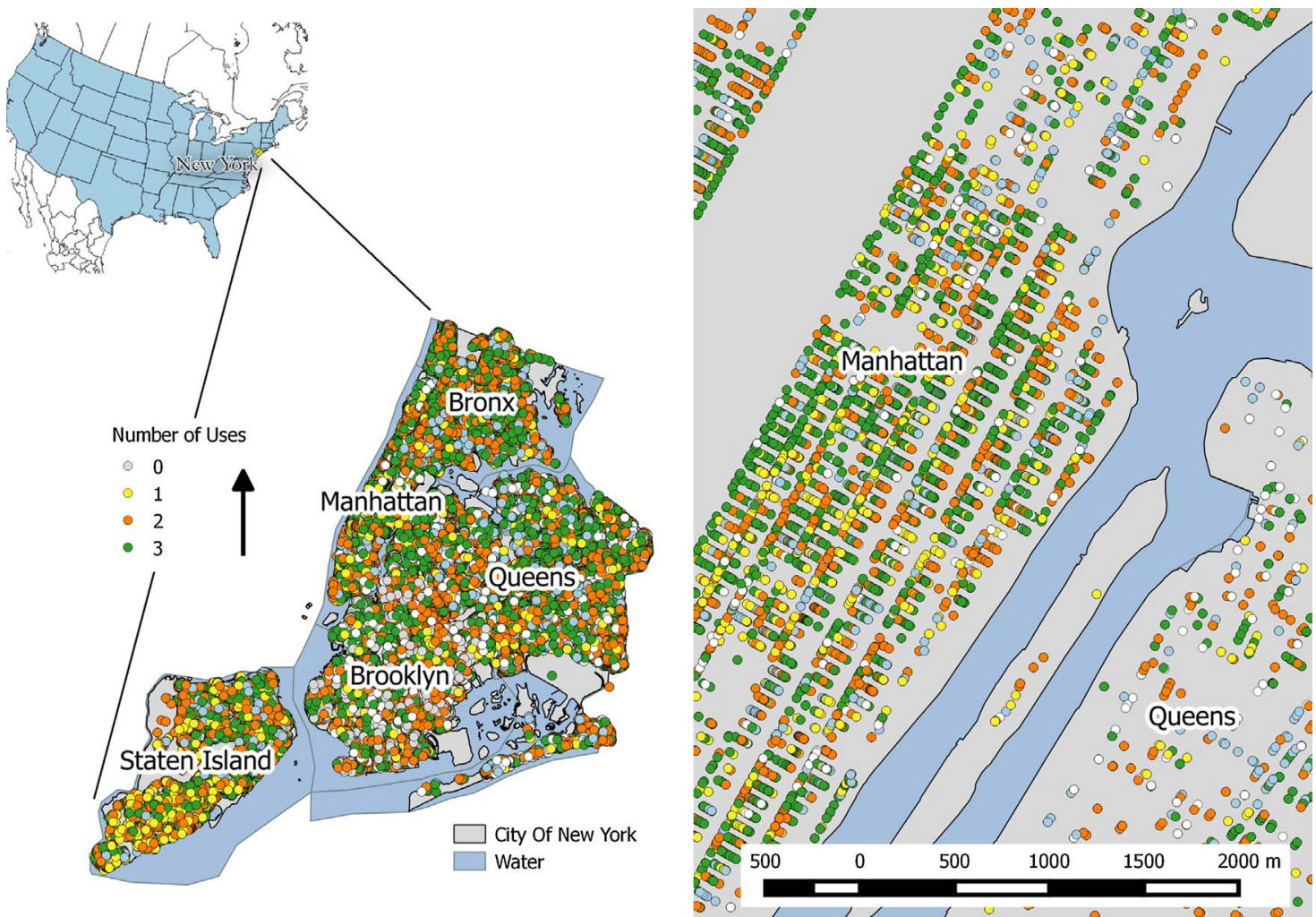

Fig. 1. New York City Street trees according to Number of Uses for that Species.

linden the most abundant among street trees. Black cherry and white mulberry also are notable for their abundance in the citywide inventory, but have relatively low abundance as street trees. In contrast, ginkgo is abundant as a street tree but occurs infrequently elsewhere in the city. However, this count may overestimate the supply of forageable ginkgo, as the part generally used is the fruit from female trees, which the city endeavors to avoid. The most abundant medicinal species found city wide with desirability ratings of three or more are tree-of-heaven, sweetgum, white mulberry, and sassafras. Littleleaf linden is similarly common among street trees. Many other medicinal species, such as red elm and balsam fir are less than $0.001 \%$ of total street trees and do not rate high in abundance elsewhere in the city.

\section{Discussion}

Results from our analyses demonstrate that New York City's urban forest contains a sizable supply of potential provisioning ecosystem services. The intersection of urban forest inventories, foraging field guides and the Plants For a Future database shows a substantial stock of street trees and woody species citywide with edible, medicinal, and other uses. This includes a majority of woody species in the city's urban forest that score 3.00 or higher for edibility, with just over 30 percent having similar medicinal ratings. Spatial distributions of these species suggest that some parts of the city may contain higher concentrations of desirable species than others. However, many of the most desirable species are not abundant in the city and may be particular scarce in some boroughs. Here, differences in urban greenspace types may make a difference in distribution and abundance of species, as suggested by the cases of mulberry (citywide) and ginkgo (as a street tree).

Our analyses are a snapshot of the supply of provisioning ecosystem services from woody species in New York City at a particular moment in time and are subject to limitations in the data we employ. Since these data were collected, the composition of the city's forest has been influenced by major weather events, among them an ice storm in 2008 and hurricane in 2014, as well as a large tree planting campaign that expanded the species palette. Our results almost certainly under- 
Table 5

Most Abundant Street Trees, their Uses and Counts by Borough.

\begin{tabular}{|c|c|c|c|c|c|c|c|c|c|c|}
\hline \multicolumn{2}{|c|}{ Number of Uses/Use/Borough } & \multirow{2}{*}{$\frac{\text { Food }}{\mathrm{X}}$} & \multirow{2}{*}{$\begin{array}{l}\text { Medicine } \\
\mathrm{X}\end{array}$} & \multirow{2}{*}{$\begin{array}{l}\text { Other } \\
\mathrm{X}\end{array}$} & \multirow{2}{*}{$\begin{array}{l}\text { Entire City } \\
43,942\end{array}$} & \multirow{2}{*}{$\begin{array}{c}\text { Bronx } \\
5124\end{array}$} & \multirow{2}{*}{$\begin{array}{l}\text { Brook-lyn } \\
9813\end{array}$} & \multirow{2}{*}{$\begin{array}{l}\text { Man-hattan } \\
2670\end{array}$} & \multirow{2}{*}{$\begin{array}{c}\text { Queens } \\
19,491\end{array}$} & \multirow{2}{*}{$\begin{array}{l}\text { Staten Island } \\
6844\end{array}$} \\
\hline 3 & Pin oak (Quercus palustris) & & & & & & & & & \\
\hline & Littleleaf linden (Tilia cordata) & $\mathrm{X}$ & $\mathrm{X}$ & $\mathrm{X}$ & 27,687 & 3169 & 8097 & 3094 & 11,628 & 1699 \\
\hline & Green ash (Fraxinus pennsylvanica) & $\mathrm{X}$ & $\mathrm{X}$ & $\mathrm{X}$ & 20,643 & 2102 & 4556 & 912 & 9431 & 3642 \\
\hline & Red maple (Acer rubrum) & $\mathrm{X}$ & $\mathrm{X}$ & $\mathrm{X}$ & 20,282 & 1857 & 2328 & 211 & 7122 & 8764 \\
\hline & Silver maple (Acer saccharinum) & $\mathrm{X}$ & $\mathrm{X}$ & $\mathrm{X}$ & 18,699 & 923 & 1978 & 85 & 10,200 & 5513 \\
\hline & Ginkgo (Ginkgo biloba) & $\mathrm{X}$ & $\mathrm{X}$ & $\mathrm{X}$ & 16,269 & 1972 & 3863 & 4893 & 4957 & 584 \\
\hline & Northern red oak (Q. rubra) & $\mathrm{X}$ & $\mathrm{X}$ & $\mathrm{X}$ & 11,086 & 1586 & 2102 & 1149 & 5192 & 1057 \\
\hline & Japanese pagoda tree (Sophora japonicum) & $\mathrm{X}$ & $\mathrm{X}$ & $\mathrm{X}$ & 7071 & 881 & 2229 & 1643 & 2043 & 275 \\
\hline & Silver linden (T. tomentosa) & $\mathrm{X}$ & $\mathrm{X}$ & $\mathrm{X}$ & 6017 & 525 & 1851 & 488 & 2910 & 243 \\
\hline & American elm (Ulmus americana) & $\mathrm{X}$ & $\mathrm{X}$ & $\mathrm{X}$ & 5468 & 675 & 1733 & 1304 & 1450 & 306 \\
\hline \multirow[t]{10}{*}{2} & Purpleleaf plum (Prunus cerasifera) & $\mathrm{X}$ & $\mathrm{X}$ & $\mathrm{X}$ & 4796 & 437 & 798 & 160 & 2331 & 1070 \\
\hline & Norway maple (Acer platanoides) & $\mathrm{X}$ & $\mathrm{X}$ & & 74,856 & 7296 & 15,672 & 556 & 43,865 & 7467 \\
\hline & Honey locust (Gleditsia triacanthos) & $\mathrm{X}$ & $\mathrm{X}$ & & 52,234 & 7579 & 12,484 & 11,529 & 17,154 & 3488 \\
\hline & Sweetgum (Liquidambar styraciflua) & $\mathrm{X}$ & $\mathrm{X}$ & & 8390 & 507 & 1059 & 126 & 1803 & 4895 \\
\hline & Crimson King Norway maple (A. platanoides $C R$ ) & $\mathrm{X}$ & $\mathrm{X}$ & & 8146 & 374 & 1467 & 10 & 3014 & 3281 \\
\hline & American linden (Tilia americana) & $\mathrm{X}$ & $\mathrm{X}$ & & 7237 & 1023 & 2023 & 708 & 3067 & 416 \\
\hline & Japanese maple (Acer palmatum) & $\mathrm{X}$ & & $\mathrm{X}$ & 2842 & 198 & 561 & 19 & 1416 & 648 \\
\hline & Chinese elm (Ulmus parviflora) & $\mathrm{X}$ & $\mathrm{X}$ & & 1988 & 413 & 389 & 285 & 594 & 307 \\
\hline & Crabapple (Malus spp.) & $\mathrm{X}$ & $\mathrm{X}$ & & 1958 & 141 & 359 & 387 & 802 & 269 \\
\hline & White oak (Q. alba) & $\mathrm{X}$ & $\mathrm{X}$ & & 1667 & 258 & 335 & 123 & 647 & 304 \\
\hline \multirow[t]{10}{*}{1} & Callery pear (Pyrus calleryana) & $\mathrm{X}$ & & & 63,665 & 4472 & 9488 & 7751 & 17,447 & 24,507 \\
\hline & Amur maple (Acer ginnala) & $\mathrm{X}$ & & & 1568 & 340 & 186 & 26 & 652 & 364 \\
\hline & Colorado spruce (Picea pungens) & $\mathrm{X}$ & & & 391 & 11 & 106 & 2 & 206 & 66 \\
\hline & Common apple (Malus pumila) & $\mathrm{X}$ & & & 114 & 8 & 21 & 31 & 33 & 21 \\
\hline & Kousa dogwood (Cornus kousa) & $\mathrm{X}$ & & & 85 & 1 & 20 & 8 & 45 & 11 \\
\hline & American hornbeam (Carpinus carolinia) & & $\mathrm{X}$ & & 63 & 1 & 25 & 1 & 25 & 11 \\
\hline & Scarlet oak (Q. coccinea) & & & $\mathrm{X}$ & 56 & 17 & 12 & 2 & 20 & 5 \\
\hline & Amur Maackia (Maackia amurensis) & $\mathrm{X}$ & & & 49 & 3 & 5 & 0 & 28 & 13 \\
\hline & Royal paulownia (Paulownia tomentosa) & & $\mathrm{X}$ & & 43 & 3 & 8 & 0 & 20 & 12 \\
\hline & Atlantic white cedar (Chamaecyparis thyoides) & & & $\mathrm{X}$ & 38 & 0 & 0 & 0 & 36 & 2 \\
\hline
\end{tabular}
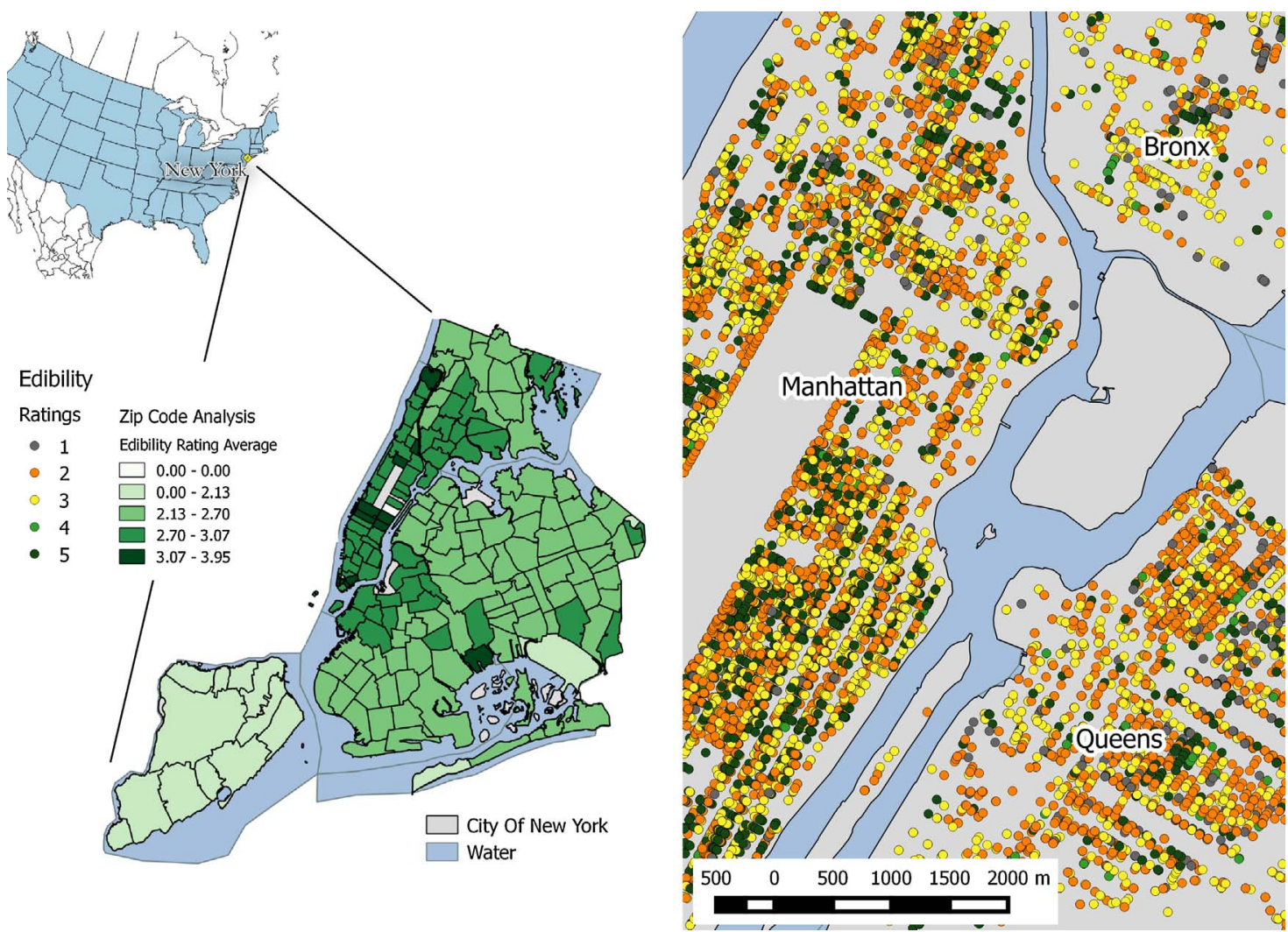

Fig. 2. Map of Selected Street Trees according to their Edibility Ratings and Average Ediblity Rating by Zip Code (PFAF, 2015). 
Table 6

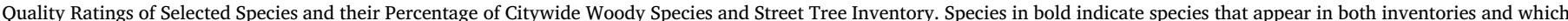

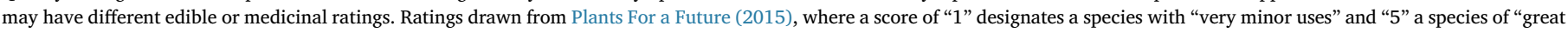
value".

\begin{tabular}{|c|c|c|c|c|c|}
\hline Rating & Species & Citywide (percent) & Street Tree (percent) & Food & Medicine \\
\hline \multirow[t]{8}{*}{5} & - Sassafras (Sassafras albidum) & $4.8 \%$ & & Yes & \\
\hline & - Littleleaf Linden (Tilia cordata) & & $4.4 \%$ & Yes & \\
\hline & - Ginkgo (Ginkgo biloba) & NA & $2.6 \%$ & Yes & Yes \\
\hline & - Littleleaf linden & $0.3 \%$ & & Yes & \\
\hline & - Nectarine (Prunus persica) & $0.2 \%$ & & Yes & \\
\hline & - Red elm (Ulmus rubra) & & 95 trees & & Yes \\
\hline & - Witch hazel (Hamamelis virginiana) & & 6 trees & & Yes \\
\hline & - Balsam fir (Abies balsamea) & & 5 trees & & Yes \\
\hline \multirow[t]{10}{*}{4} & - Black cherry (P. serrotina) & $8.1 \%$ & & Yes & \\
\hline & - White mulberry (Morus alba) & $5.7 \%$ & & Yes & \\
\hline & - Purpleleaf plum (P. cersifera) & & $0.8 \%$ & Yes & \\
\hline & - Sugar maple (Acer rubrum) & $0.3 \%$ & $0.7 \%$ & Yes & \\
\hline & - Rose-of-Sharon (Hibiscus syriacus) & $0.2 \%$ & & Yes & \\
\hline & - Cherry plum (P. cersifera) & $0.2 \%$ & & Yes & \\
\hline & - Horse chestnut (Aesculus hippocastanum) & & $0.2 \%$ & & Yes \\
\hline & - European beech (Fagus sylvatica) & $0.1 \%$ & & Yes & \\
\hline & - Swamp white oak (Q. bicolor) & $0.1 \%$ & $0.1 \%$ & Yes & \\
\hline & - Black cherry (P. serrotina) & & 188 trees & Yes & \\
\hline \multirow[t]{14}{*}{3} & - Tree of heaven (Ailanthus altissima) & $9.0 \%$ & & & Yes \\
\hline & - Sweetgum (Liquidambar styraciflua) & $7.9 \%$ & & & Yes \\
\hline & - White mulberry & $5.7 \%$ & & & Yes \\
\hline & - Sassafras & $4.8 \%$ & & & Yes \\
\hline & - Littleleaf linden & & $4.4 \%$ & & Yes \\
\hline & • Sweetgum & & $1.3 \%$ & & Yes \\
\hline & - American linden & & $1.2 \%$ & & Yes \\
\hline & - Japanese pagoda tree (Styphnolobium japonicum) & & $1.1 \%$ & & Yes \\
\hline & - Black oak (Q. velutina) & $0.7 \%$ & & & Yes \\
\hline & - Eastern hemlock (Tsuga canadensis) & $0.5 \%$ & & & Yes \\
\hline & - Eastern white pine (Pinus strobus) & $0.3 \%$ & & & Yes \\
\hline & - Balsam poplar (Populus balsamifera) & $0.3 \%$ & & & Yes \\
\hline & - Tree of heaven & & $0.2 \%$ & & Yes \\
\hline & - American linden & $0.2 \%$ & & & Yes \\
\hline
\end{tabular}
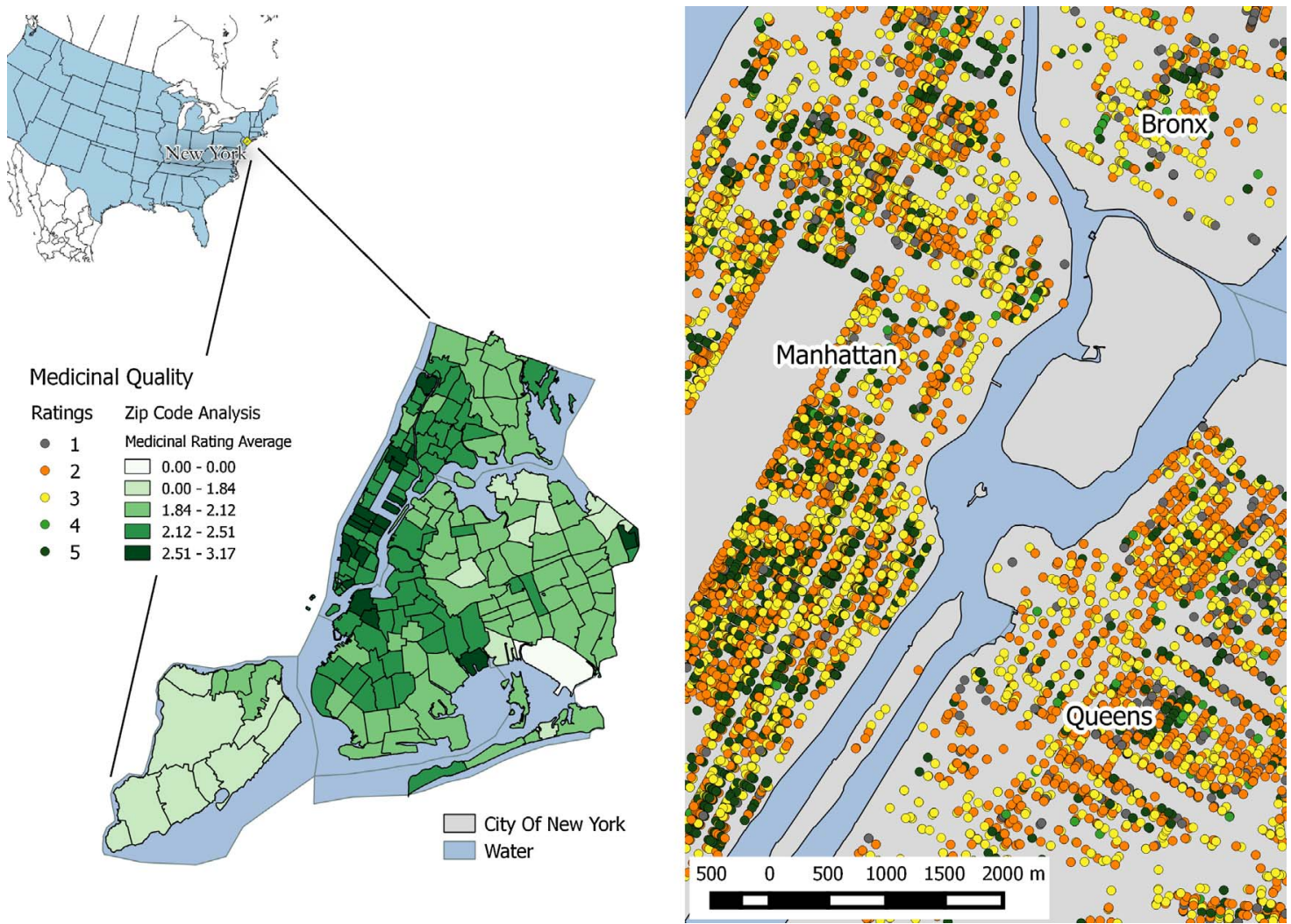

Fig. 3. Map of Selected Street Trees according to their Medicinal Ratings and Average Medicinal Rating by Zip Code (PFAF, 2015). 
represent the supply of forageable species present in New York City greenspaces at the time represented by the data, due to its sole focus on woody species. Studies conducted in several U.S. cities point to the range of non-woody plants and fungi foraged by urban residents (Poe et al., 2013), species which are entirely missing from our analysis. Lack of data on several highly desirable woody species, such as berries in the genus Rubus, is a source of under-counting in the class of plants that are the primary focus of this study. Documentation of numbers of foragers and foraged volumes will be needed to estimate the provisioning ecosystem services actually provided by urban green infrastructure. Until such time as these data are available, surrogates such as the PFAF desirability ratings provide a basis for identifying likely foraged species.

Our approach offers a method for analyzing understudied provisioning ecosystem services from urban greenspaces. Future research on the supply and distribution of forageable species in urban greenspaces would benefit from updated inventories, inclusion of understory shrubs and non-woody plants, and data on the full range of vegetated land uses including interstitial spaces (Galt, Grey, \& Hurley, 2014). While we have confined our spatial analyses here to woody species city wide and the subset of those in the street tree inventory, more detailed analysis of vegetation by land-use categories would yield further understandings of the relationship between greenspace elements and the supply of forageable material in a city's urban green infrastructure, as well as how this may change through time in response to policy and management actions such as expansion of street tree planting palettes.

Harkening back to the Seattle urban forest management handbook (Floberg et al., 2013), we note that the provisioning ecosystem services provided by urban green infrastructure through foraging are intertwined with cultural ecosystem services. The relationship between provisioning and cultural ecosystem services from urban foraging is further confirmed by research conducted in Spain (Reyes-García et al., 2015) and South Africa (Cocks et al., 2016). As a consequence, future research on urban foraging also will broaden understanding of the cultural ecosystem services provided by diverse urban greenspace elements. Here, we note that spatial analyses of intersections (or lack thereof) in supply of culturally significant foraged foods, medicines, and other materials with human demographics and transportation networks will be necessary to understand accessibility of culturally salient forageable species. Doing so also will provide insights into frequency of harvest and specific material benefits resulting from foraging practices.

In the United States, most municipalities prohibit foraging on public lands. Our research suggests public health and sustainability concerns underlie these prohibitions (unpublished data). Until such time as sufficient toxicology research is available to determine the effects of urban legacies on the safety of urban foraged foods (see von Hoffen \& Säumel, 2014), the growing body of such research for urban farms and gardens offers some guidelines (see, for example, Kim et al., 2014).

Determining the supply for forageable species is necessary but insufficient to assess the sustainability of urban foraging and the provisioning ecosystem services it provides. Foraging sustainability is a function of interacting social and ecological factors that may change through time (Emery, 1998; Hurley et al., 2012). Among these factors are demand, species ecology, foraging strategies, and habitat sensitivity. For example, foods considered undersirable by one culture may be central to the cuisine of another. The impact of bark harvesting from branches pruned in the course of urban forest management is different from that of removing bark from the boles of standing, live trees. Further research would be needed to understand these dynamics of urban foraging and forms of governance that could support it as a source of provisioning ecosystem services over the long-term. Given the dozens to hundreds of species likely foraged in most cities, developing governance strategies may be facilitated by tailoring rules to three categories of species: (a) those needing active management and protection, (b) those not requiring direct management or protection to sustain populations, and (c) those meriting further research and monitoring to determine appropriate policy and management approaches (Emery and Ginger, 2014).

\section{Conclusions}

Our results show that species and spaces outside those explicitly designated for food production are potential sources of provisioning ecosystem services. Coupled with the growing literature on foraging in cities around the world, they suggest an as yet unquantified volume of provisioning ecosystem services actually are derived from diverse urban greenspace elements. These findings have implications for accountings of ecosystem services from urban green infrastructure, as well as policy and management initiatives to enhance social-ecological resilience.

Some quantitative and qualitative accountings of urban ecosystem services have expanded beyond regulating and supporting services to include cultural and provisioning services. This study suggests the opportunity to further enlarge the scope of provisioning ecosystem services calculations and offers one method for doing so. Since food and medicine often have strong cultural valences, such accountings also would contribute to understanding a broader range of cultural ecosystem services from urban greenspaces.

Cities increasingly look to urban green infrastructure to provide multi-functional benefits, from stormwater management to improved public health. Policy and management considerations of urban foraging as one of those ecosystem services will benefit from additional research on the social-ecological dynamics of this practice. Studies of the ecological dynamics of urban foraging would include factors including habitat sensitivity, harvest timing, species ecology, and response to specific harvest techniques. Among the social dynamics needing further investigation are distributional justice of forageable species, opportunities to engage foragers as allies in urban greenspace stewardship, and human health benefits and potential risks from foraging and consuming urban plant materials and fungi. There also may be prospects for incorporating provisioning from foraging into strategies for enhancing other greenspace ecosystem services, such as including forageable species in urban riparian management plantings.

In recognizing urban foraging as a component of its efforts to enhance food and health sovereignty and justice, the City of Seattle eloquently makes the case that this practice can contribute to social-ecological resilience. Further, the Seattle urban forest management handbook notes that "Gathering offers positive physical and mental health benefits" (Floberg et al., 2013:33). As other cities determine whether and how they may wish to embrace foraging and its benefits for human wellbeing, additional research will be needed. The study reported on here, together with those summarized above, are an initial step in that direction.

\section{Acknowledgments}

We thank the staff of the U.S. Department of Agriculture, Forest Service and New York City Department of Parks and Recreation Department's New York City Urban Field Station for their support during field visits and for feedback on aspects of this project. Jessie Breen provided GIS support during the project. Assistance with data collection came from Joe Palladino. Funds for Hurley's travel came from the Department of Environmental Studies and the Office of the Dean at Ursinus College. The comments of two anonymous reviewers improved the manuscript greatly.

\section{References}

Barthel, S., Folke, C., \& Colding, J. (2010). Social-ecological memory in gardening: Retaining the capacity for management of ecosystem services. Global Environmental Change, 20, 255-265. http://dx.doi.org/10.1016/j.gloenvcha.2010.01.001.

Barthel, S., Parker, J., \& Ernstson, H. (2013). Food and green space in cities: A resilience lens on gardens and urban environmental movements. Urban Studies, 2013, 1321-1338. http://dx.doi.org/10.1177/0042098012472744. 
Barthel, S., Parker, J., Folke, C., \& Colding, J. (2014). Urban gardens-pockets of social-ecological memory. In K. G. Tidball, \& M. E. Krasny (Eds.). Greening in the red zone: Disaster, resilience, and urgent biophiliaDordrecht: Springer. http://dx.doi.org/10. 1007/978-90-481-9947-1_11.

Benedict, M. A., \& McMahon, E. T. (2012). Green infrastructure: Linking landscapes and communities. [Island, Washington, DC].

Campbell, L. K., Svendsen, E. S., Sonti, N. F., \& Johnson, M. L. (2016). A social assessment of urban parkland: Analyzing park use and meaning to inform management and resilience planning. Environmental Science \& Policy. http://dx.doi.org/10.1016/j.envsci. 2016.01.014.

Campbell, L. K. (2014). Constructing New York City's urban forest. The politics and governance of the MillionTreesNYC campaign. In L. A. Sandberg, A. Bardekjian, \& S. Butt (Eds.). Urban forests, trees and greenspace. A policy perspective. New York, NY: Routledge.

Chen, W. Y., \& Jim, C. Y. (2008). Assessment and valuation of the ecosystem services provided by urban forests. In M. M. Carreiro, Y. C. Song, \& J. Wu (Eds.). Ecology, planning and management of urban forests (pp. 53-83). New York: Springer. http://dx. doi.org/10.1007/978-0-387-71425-7 5.

Chen, B., Adimo, O. A., \& Bao, Z. (2009). Assessment of aesthetic quality and multiple functions of urban green space from the users' perspective: The case of Hangzhou flower garden, China. Landscape and Urban Planning, 93(1), 76-82. http://dx.doi.org/ 10.3390/ijerph14070766.

Chiusura, A. (2004). The role of urban parks for the sustainable city. Landscape and Urban Planning, 68, 129-138. http://dx.doi.org/10.1016/j.landurbplan.2003.08.003.

Clark, K. H., \& Nicholas, K. A. (2013). Introducing urban food forestry: A multifunctional approach to increase food security and provide ecosystem services. Landscape Ecology, 28(9), 1649-1669. http://dx.doi.org/10.1007/s10980-013-9903-z.

Cocks, M., Alexander, J., Mogano, L., \& Vetter, S. (2016). Ways of belonging: Meanings of nature among Xhosa-speaking township residents in South Africa. Journal of Ethnobiology, 36(4), 820-841. http://dx.doi.org/10.2993/0278-0771-36.4.820.

D'Souza, R., \& Nagendra, H. (2011). Changes in public commons as a consequence of urbanization: The Agara Lake in Bangalore, India. Environmental Management, 47(5), 840-850. http://dx.doi.org/10.1007/s00267-011-9658-8.

Del Tredici, P. D. (2010). Spontaneous urban vegetation: Reflections of change in a globalized world. Nature and Culture, 5(3), 299-315. http://dx.doi.org/10.3167/nc 2010.050305.

Elmqvist, T., Fragkias, M., Goodness, J., Güneralp, B., Marcotullio, P. J., McDonald, R. I., Parnell, S., Schewenius, M., Sendstad, M., Seto, K., \& Wilkinson, C. (Eds.). (2013). Urbanization, biodiversity and ecosystem services: challenges and opportunities: a global assessmentNew York, NY: Springer. http://dx.doi.org/10.1007/978-94-007-7088-1.

Emery, M. R., \& Ginger, C. (2014). Special forest products on the green mountain and finger lakes national forests: A research-based approach to management. general technical report NRS-131Newtown Square, PA: U.S. Department of Agriculture, Forest Service, Northern Research Station.

Emery, M. R. (1998). Invisible livelihoods: Non-timber forest products in michigan's upper peninsula. Ann Arbor, MI: UMI [Dissertation Services].

Floberg, J., Small, J., Bradley, G., Early, T., Fixen, L., Mega, M., ... Staeheli, P. (2013). City of Seattle 2013 urban forest stewardship plan. Seattle, WA: Urban Forestry Commission.

Galt, R. E., Gray, L. C., \& Hurley, P. (2014). Subversive and interstitial food spaces: Transforming selves, societies, and society-environment relations through urban agriculture and foraging. Local Environment, 19(2), 133-146. http://dx.doi.org/10. 1080/13549839.2013.832554.

Gargiullo, M. B. (2007). A guide to native plants of the New York City region. New York, NY: New York City Department of Parks \& Recreation.

Grabbatin, B., Hurley, P., \& Halfacre, A. (2011). I still have the old tradition: The coproduction of sweetgrass basketry and coastal development. Geoforum, 42.6, 638-649. http://dx.doi.org/10.1016/j.geoforum.2011.06.007.

Grimm, N. B., Faeth, S. H., Golubiewski, N. E., Redman, C., Wu, J., Bai, X., \& Briggs, J. M. (2008). Global change and the ecology of cities. Science, 319, 756-760. http://dx.doi. org $/ 10.1126 /$ science.1150195.

Haase, D., Frantzeskaki, N., \& Elmqvist, T. (2014). Ecosystem services in urban landscapes: Practical applications and governance implications. Ambio, 43, 407-412. http://dx.doi.org/10.1007/s13280-014-0503-1.

Hurley, P., Grabbatin, B., Goetcheus, C., \& Halfacre, A. (2012). Gathering, buying, and growing sweetgrass (Muhlenbergia sericea): Urbanization and social networking in the sweetgrass basket-Making industry of lowcountry south carolina. In R. Voeks, \& J. Rashford (Eds.). African ethnobotany in the AmericasSpringer Verlaghttp://dx.doi.org/ 10.1007/978-1-4614-0836-9_6.

Hurley, P., Emery, R., McLain, M., Grabbatin, B., \& Goetcheus, C. (2015). Whose urban forest? The political ecology of gathering urban NonTimber Forest Products. In C. Isenhour, M. Checker, \& G. McDonogh (Eds.). Sustainability in the global city: Myth and practiceCambridge University Presshttp://dx.doi.org/10.1017/CBO9781139923316. 014.

Kaoma, H., \& Shackleton, C. M. (2014). Collection of urban tree products by households in poorer residential areas of three South African towns. Urban Forestry \& Urban Greening, 13, 244-252. http://dx.doi.org/10.1016/j.ufug.2014.02.002.

Kim, B. F., Poulsen, M. N., Margulies, J. D., Dix, K. L., Palmer, A. M., \& Nachman, K. E.
(2014). Urban community gardeners' knowledge and perceptions of soil contaminant risks. PLoS One, 9(2), http://dx.doi.org/10.1371/journal.pone.0087913.

Konijnendijk, C. C., Annerstedt, M., Nielsen, A. B., \& Maruthaveeran, S. (2013). Benefits of urban parks: A systematic reviewCopenhagen, Denmark \& Alnarp, Sweden: A Report to the International Federation of Parks and Recreation Administration.

Konijnendijk van den Bosch, C. (2008). The forest and the city - The cultural landscape of urban woodlands. Dordrecht, The Netherlands: Springer Verlag.

Larondelle, N., \& Strohbach, M. W. (2016). A murmur in the trees to note: Urban legacy effects on fruit trees in Berlin, Germany. Urban Forestry \& Urban Greening, 17, 11-15. http://dx.doi.org/10.1016/j.ufug.2016.03.005.

Maas, J., Verheij, R. A., Groenewegen, P. P., de Vries, S., \& Spreeuwen-berg, P. (2006). Green space, urbanity, and health: How strong is therelation? Journal of Epidemiology and Community Health, 60(7), 587-592. http://dx.doi.org/10.1136/jech.2005. 043125.

McLain, R., Poe, M., Hurley, P., Lecompte-Mastenbrook, J., \& Emery, M. (2012). Producing edible landscapes in Seattle's urban forest. Urban Forestry \& Urban Greening, 11, 187-194. http://dx.doi.org/10.1016/j.ufug.2011.12.002.

McLain, R., Hurley, P., Emery, M., \& Poe, M. (2014). Gathering wild food in the city: Rethinking the role of foraging in urban ecosystem planning and management. Local Environment, 19(2), 220-240. http://dx.doi.org/10.1080/13549839.2013.841659.

New York City Open Data (2015). 2005 street tree census. https://nycopendata.socrata. com/browse? q = Street\%20Tree\%20Census. [Accessed 25 March 2016].

New York Flora Association (2017). New York flora atlas. http://newyork.plantatlas.usf. edu/. [Accessed 24 July 2017].

New York Metropolitan Flora Project (2015). New York metropolitan flora project. http:// nymf.bbg.org/contents.asp. [Accessed 25 March 2016].

Nowak, D. J., Hoehn, R. E., III, Crane, D. E., Stevens, J. C., \& Walton, J. T. (2007). Assessing urban forest effects and values, New York City's urban forest. Newtown Square, PA: Resource Bulletin NRS-9. U.S. Department of Agriculture, Forest Service, Northern Research Station.

Palliwoda, J., Kowarik, I., \& von der Lippe, M. (2017). Human-biodiversity interactions in urban parks: The species level matters. Landscape and Urban Planning, 157, 394-406. http://dx.doi.org/10.1016/j.landurbplan.2016.09.003.

Plants For a Future (2015). Plants for a future: a resource and information centre for edible and otherwise useful plants. http://www.pfaf.org/user/Default.aspx. [Accessed 24 July 2017].

Poe, M. R., McLain, R. J., Emery, M., \& Hurley, P. T. (2013). Urban forest justice and the rights to wild foods, medicines, and materials in the city. Human Ecology, 41(3), 409-422. http://dx.doi.org/10.1007/s10745-013-9572-1.

Poe, M., LeCompte-Mastenbrook, J., McLain, R., \& Hurley, P. (2014). Urban foraging and relational ecologies of belonging. Social and Cultural Geography, 15(8), 901-919. http://dx.doi.org/10.1080/14649365.2014.908232.

Reyes-García, V., Menendez-Baceta, G., Aceituno-Mata, L., Acosta-Naranjo, R., CalvetMir, L., Domínguez, P., ... Rodríguez-Franco, R. (2015). From famine foods to delicatessen: interpreting trends in the use of wild edible plants through cultural ecosystem services. Ecological Economics, 120, 303-311. http://dx.doi.org/10.1016/j. ecolecon.2015.11.003.

Robbins, P., Emery, M., \& Rice, J. L. (2008). Gathering in Thoreau's backyard: Nontimber forest product harvesting as practice. Area, 40(2), 265-277. http://dx.doi.org/10. 1111/j.1475-4762.2008.00794.x.

Seth, M. K. (2003). Trees and their economic importance. The Botanical Review, 69(4), 321-376. http://dx.doi.org/10.1663/0006-8101(2004)069[0321:TATEI]2.0.CO;2.

Shackleton, C., Shackleton, S., \& Shanley, P. (2011). Building a holistic picture: An integrative analysis of current and future prospects for non-timber forest products in a changing world. Berlin, Germany: Springerhttp://dx.doi.org/10.1007/978-3-642 17983-9.

Shackleton, S., Chinyimba, A., Hebinck, P., \& Shackleton, C. (2015). Multiple benefits and values of trees in urban landscapes in two towns in northern South Africa. Landscape and Urban Planning, 136, 76-86. http://dx.doi.org/10.1016/j.landurbplan.2014.12. 004.

Tyrväinen, L., Pauleit, S., Seeland, K., \& De Vries, S. (2005). Benefits and uses of urban forests and trees. In C. C. Konijnendijk, K. Nilsson, T. P. Randrup, \& J. N. Schipper (Eds.). Urban forests and trees (pp. 81-114). Heidelberg: Springer. http://dx.doi.org/ 10.1007/3-540-27684-X.

U.S. Census Bureau (2015). Quick facts: New York. http://quickfacts.census.gov/qfd/ states/36000.html Accessed 16.03.25.

Unnikrishnan, H., \& Nagendra, H. (2015). Privatizing the commons: Impact on ecosystem services in Bangalore's lakes. Urban Ecosystems, 18(2), 613-632. http://dx.doi.org/ 10.1007/s11252-014-0401-0.

von Hoffen, L. P., \& Säumel, I. (2014). Orchards for edible cities: Cadmium and lead content in nuts, berries, pome and stone fruits harvested within the inner city neighbourhoods in Berlin, Germany. Ecotoxicology and Environmental Safety, 101, 233-239. http://dx.doi.org/10.1016/j.ecoenv.2013.11.023.

Wehi, P. M., \& Wehi, W. L. (2010). Traditional plant harvesting in contemporary fragmented and urban landscapes. Conservation Biology, 24, 594-604. http://dx.doi.org/ 10.1111/j.1523-1739.2009.01376.x. 